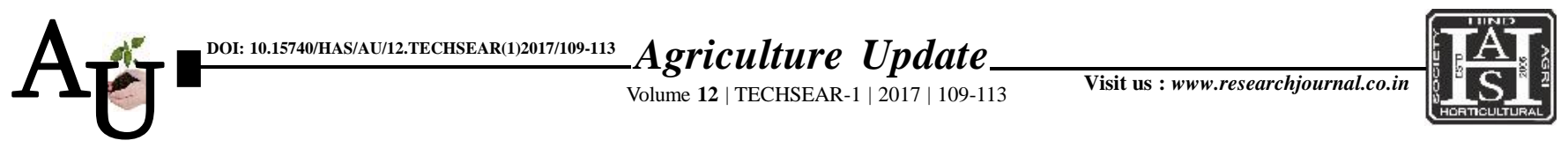

口 e ISSN-0976-6847

\title{
Rеввавсн автісів: Estimation of yield losses due to sucking pests of Bt cotton under high density planting system
}

\author{
TUKARAM A. NIKAM, C.B. LATPATE AND P.R. ZANWAR
}

Article Chronicle:

Received :

05.07.2017;

Accepted :

22.07.2017

SUMMARY : Studies was carried out during Kharif 2015-16 and 2016-17 to investigate on estimation of yield losses due to sucking pests viz., aphids, leafhoppers, thrips and whiteflies, the unprotected treatments recorded significantly higher aphid population over protected ones with $14.81,5.61,15.08$, 12.41 and 3.66, 1.90, 3.83, 1.81 sucking pest per three leaves, respectively, with $75.29,66.13,74.63$ and 85.41 per cent overall increase in population in the unprotected treatments over protected treatments ones. The yield differed with protection irrespective of protected and unprotected condition observed that on an average significantly more yield $(18.67 \mathrm{q} / \mathrm{ha})$ was obtained under protected condition as compared to unprotected condition (12.47 q/ha) with avoidable loss of 33.02 per cent by unprotected condition over protected condition ones.

How to cite this article : Nikam, Tukaram A., Latpate, C.B. and Zanwar, P.R. (2017). Estimation of yield losses due to sucking pests of $B t$ cotton under high density planting system. Agric. Update, 12(TECHSEAR-1) : 109. 113; DOI: 10.15740/HAS/AU/12.TECHSEAR(1)2017/109-113.

Key Words:

Yield losses, Sucking pests, High density planting system, $\mathrm{Bt}$ cotton, Protected condition

Author for correspondence :

\section{TUKARAM A. NIKAM} Department of Agricultural Entomology, Vasantrao Naik Marathwada Agriculture University, PARBHANI (M.S.) INDIA Email:tukaramnikam.agri@ gmail.com

See end of the article for authors' affiliations 